\title{
STRIVING FOR ADVANTAGE AS A DETERMINANT OF SOCIAL BEHAVIOUR
}

\author{
Adolfas Juodraitis, Liuda Radzevičienè \\ Šiauliai University, Lithuania \\ E-mail: sppkatedra@cr.su.It, raliu@splius.It
}

\begin{abstract}
After the experience of alienation, insecurity, distrust and dismay in the family, getting into institutional care teenager is forced to feel it once more, on the other hand, new environment and intermittent situation in the care institution leads teenager to look for new ways for social interaction and often these ways are limited due to the peculiarities of teenager's psychosocial development. It is complicated for youngster to master new and unusual forms of social interactions that are based on common activities and result planning, social activity and responsibility, because stereotypes of teenagers' behaviour and reactions in the different situations cannot change so fast. The lack of social skills disturbs optimal development of social networks, determines low level of self control, decreases ability to solve conflict situations constructively, so usually they are forced to use known behavioural strategies (to behave aggressively and provocative in order to get advantage). In such situation the demonstration of advantage gets a specific attribution and transforms to the manifestations of concurrent aggression that are evident more and more often. Concurrent aggression determines complicated and difficult relationships between teenagers, institutional staff as well and with environment in general. The paper presents research which aim is to define concurrent behaviour among teenagers who are placed in the institutional care. With the authors' permission approbated check list of self evaluation YSR 11/18 (Youth self report, Achenbach, Rescoria, 2001) was used and 14 - 17 years old 126 teenagers from different care institutions of Lithuania took place in the research. Approbated check list YSR 11/18 (Žukauskiené, Malinauskienè, 2008) consists of 20 statements that reveal social and behaviour (activeness) competences and 122 statements that let for the researcher to assess problems in behavioural and emotional performance. Six scales were used: anxiety/depression, withdrawal/depression, rules breaking, aggressive behaviour and scale of attention and social problems. The data of quantitative research point out those statistically significant correlate results of behaviour and emotional problems; the strongest ties among the teenagers group were set up between aggressive behaviour and breaking of the rules. The results of correlation analysis proved that anxiety/depression scale of teenagers placed into the institutional care closely correlates with social problems, and social problems are in tight relations with aggressive behaviour and lack of attention and lack of attention correlates with aggressive behaviour, as well. In qualitative research 6 interviewers were involved. Applying method of narrative research the subjective point of view of teenagers on striving for domination, manifestations of aggression signs and factors that determine such their behaviour was done.
\end{abstract}

Key words: behavioural norm, concurrent aggression, institutional care.

\section{Introduction}

One of the main conditions of forming of the mature public-spirited society is a social behaviour of its members that is determined by variety, intensity and strength of influence of different variables (peculiarities of person's structure, impact of psychosocial and socio-cultural 
environment, level of economic status) that are influenced by a lot of rather different factors (biogenetic, globalization, changes in values) as well. As a significant condition of the development of person's social behaviour that determines the perspective success of socialization is the compatibility of perception of essential social norms, keeping and giving them sense. This compatibility could be contravened by many interrelating factors. Any social environment could provoke presumptions of delinquent behaviour anyway; the significant factor of risk is the person's institutionalization in different stages of his/her psychosocial development. The negative experiences traumatizing person such as insecurity and alienation in the family, dominating of aggressive behaviour in the nearest environment, the academic and communication fail in school, etc. are strengthened by shifting child into the care institution and this conditions his/ her appropriate resistance to the institutional and general social norms overall. Such situation of partly forced changes in social environment often determines specific behaviour standards, forming of specific subculture and essentially reverses qualitative parameters of psychosocial maturity. According to the integrative sociological and psychological point of view to the personality the main dimensions of psychosocial maturity are: 1) ability to act independently; 2) ability to interact with environment in the appropriate way; 3) ability to promote and develop social relations (Greenberger, Sorensen, 1974). This could be understood as person's adaptive functioning and adequate socio-emotional competences (Galambos, Tilton-Weaver, 2000; Walters, White, 1990).

The problem is that child's psychosocial development even before his/her placing into the care institution seems to be affected by different negative factors that had determined specificity of dimensions of psychosocial developmental and corresponding to social attitudes and behaviour stereotypes in the context of his/her function in society as well. It is hard to explain such changes in person's behaviour genesis according to one theory of aggression ( 22 or even combination of several of them) or by attempts in structuring separated components. In the context of discussed problem the "Appearing norm theory" seems to be more suitable than other ones and points that inadequate behaviour often occurs due to the rising of the new norms in the groups, and these new norms are keeping on in the special situations (Turner, Killian, 1972). The placement of child into the care institution is defined as a special situation. Child's care and education are safeguarded in it, the negative influence of the environment and family is eliminated but other segments of psychosocial environment manifest significantly. The regime requests that regulate person's autonomy and turn to unconditional keeping of special norms, large number of persons regulating life rhythm of child, necessity of creation and fixing new relations in the group first of all. Mentioned requests might additionally strengthen the deficit in psychosocial development transformed even before. Many researches prove that institutional environment gives additional specific features for child's development (Vorria et al, 1998; Hukkanen et al, 1999; Samašonok, Žukauskiene,, 2004, Samašonok, Juodraitis, Gudonis, 2010, Cauffman, Steinberg, 2000) and often these features manifest the reasons of social immaturity: child lost his/her sense of security, self-confidence, confidence in adults and environment (Kovalenkoviené, Leliūgienė, 2005; Radzevičienè, 2000; Ослон, 2001; Ярославцева, 2002). Such partial changes in "Self”" concept (it is considered as the dependence of self-confidence to the proportion of self perception and ideal "Self") could play a significant role choosing delinquent behaviour (Rosenberg, Rosenberg, 1978) and repeated acts of antisocial behaviour (Stoff, Breiling, Maser, 1997), in such a way trying to compensate sense of inferiority and to firm own position in the new environment.

It is common that in cases of early delinquency the peer groups are forming in rather young age and interrelate with the influence of groups in form and content as well. The main factor is the respect of peer groups that becomes the significant criterion of self-respect. Such derivative of interrelations among teenagers might be related with a sense of emptiness in the group, so peer group becomes as substitute of integration processes into adult's life and appearing other kind of norm system (delinquency) starts as a way to combat with humiliation and other cases of disrespect (Toch, 1998). Changes of social behaviour of teenagers in the psychosocial level could be influenced by exposure of advantage in the interplay with subjects of different social field (more expressed in the relationships with peer groups) and striving for higher social status substantiating it in the way of concurrent aggression. 
These considerations define the aim research - to define concurrent behaviour among teenagers who are placed in the institutional care.

\section{Methodology of Research}

Analyzing prevailing strive of teenagers, who are in the institution care, for expressed advantage in the relationship with the subjects of nearest environment, it was referred to the theory of individual psychology and one of its component - concept of fundamental strive for advantage and its personal meaning (Adler, 2008), and concept of power endeavour in Honey's (2008) sociocultural theory of personality. Both authors in their scientific thesis point out the need of domination as significant personal feature which sometimes gets negative tendencies due to the style of parenting that forms child's dismay, low self value, depression, risk of suicide, turn to delinquent behaviour. It is likely that social dysfunction of teenager links with specific style of parenting and it becomes more expressed after youngster's placement into institutional care and in this way striving for the advantage becomes a significant determinant of behavioural transformations.

With the authors' permission approbated check list of self evaluation YSR 11/18 (Youth self report, Achenbach, Rescoria, 2001) was used in the presented research and $14-17$ years old 126 teenagers from different care institutions of Lithuania took part in the research. Approbated check list YSR 11/18 (Žukauskienè, Malinauskienè, 2008) consists of 20 statements that reveal social and behaviour (activeness) competences and 122 statements that let for the researcher to assess problems in behavioural and emotional performance. Six scales were used: anxiety/depression, withdrawal/depression, rules breaking, aggressive behaviour and scale of attention and social problems. Results of anxiety/depression scale reveal isolation, instability of the participant, sense of being unloved, despair, nervous strain, stress, apprehension, and too strong sense of fault, unhappiness, and depression.

Results of withdrawal/depression scale describe feelings of loneliness, isolation, diffidence, timidity and sadness. Results of rule breaking scale points out the tendency to choose wrong friends, mendacity, stealing, missing of lessons at school, usage of psychoactive substances, turn for fire-raising. Scale of aggression reveals such problems as arguing with adults, taunt over others, menacing, naughtiness, scuffle, abrupt changes in mood, damage of property. Results of attention and social problems scale describe incapacity to concentrate in performing activities, to sit quietly in one place for some definite time, manifestations of impulsiveness and nervousness. Scale of social problems points out difficulties in interpersonal relations - too strong dependence on adults, childish behaviour, conflicts with peer groups.

In the second stage (qualitative research) of the research 6 interviewers were involved. Applying method of narrative research the subjective point of view of teenagers on striving for domination, manifestations of aggression signs and factors that determine such their behaviour was done. Results were processed using method of content analysis (rate of lexical semantic units). The validity of the results was verified by 7 independent experts (lawyers, social educator, psychologist, and education staff of institutions).

\section{Results of Research}

The data of quantitative research point out those statistically significant correlate results of behaviour and emotional problems; the strongest ties among the teenagers group were set up between aggressive behaviour and breaking of the rules. The results of correlation analysis proved that anxiety/depression scale of teenagers placed into the institutional care closely correlates with social problems, and social problems are in tight relations with aggressive behaviour and lack of attention and lack of attention correlates with aggressive behaviour, as well (see Table 1). 
Correlation analysis of behaviour and emotions problems of teenagers who are placed into institutional care.

\begin{tabular}{lcccccc}
\hline \multicolumn{1}{c}{ Scale } & $\begin{array}{c}\text { Anxietyl } \\
\text { depression }\end{array}$ & $\begin{array}{c}\text { Withdrawal/ } \\
\text { depression }\end{array}$ & $\begin{array}{c}\text { Social } \\
\text { problems }\end{array}$ & $\begin{array}{c}\text { Rules } \\
\text { breaking }\end{array}$ & $\begin{array}{c}\text { Aggressive } \\
\text { behaviour }\end{array}$ & $\begin{array}{c}\text { Attention } \\
\text { problems }\end{array}$ \\
\hline Anxiety/depression & 1.00 & $0.63^{*}$ & $0.63^{*}$ & $0.37^{*}$ & $0.38^{*}$ & $0.52^{*}$ \\
Withdrawal/depression & $0.51^{*}$ & 1.00 & $0.55^{*}$ & $0.39^{*}$ & $0.39^{*}$ & $0.49^{*}$ \\
Social problems & $0.58^{*}$ & $0.55^{*}$ & 1.00 & $0.42^{*}$ & $0.54^{*}$ & $0.59^{*}$ \\
Rules breaking & $0.19^{*}$ & $0.22^{*}$ & $0.36^{*}$ & 1.00 & $0.69^{*}$ & $0.47^{*}$ \\
Aggressive behaviour & $0.26^{*}$ & 0.11 & $0.41^{*}$ & $0.53^{*}$ & 1.00 & $0.6^{*}$ \\
Attention problems & $0.44^{*}$ & $0.31^{*}$ & $0.48^{*}$ & $0.41^{*}$ & $0.53^{*}$ & 1.00 \\
\hline Note: $\left({ }^{*} p<0.001\right)$ & & & & & &
\end{tabular}

Analyzing results it was revealed that social problems (difficulties in setting up and keeping social contacts with teenagers) are common for the institutionalized teenagers who are turned to behave aggressively $(r=0.54 ; p<0.001)$, inclined to break behavioural rules $(r=0.42 ; p<0.001)$ and have problems in the concentration of attention $(\mathrm{r}=0.59 ; \mathrm{p}<0.001)$. Mentioned personal features of teenagers are going to transform into complicated interrelations and determine constant competition in the fictitious hierarchy among teenagers.

The research reveals that teenagers who are placed into institutional care have lower expressed scores in extraversion $(p=0.004)$, communication $(p=0.001)$, honesty/consciousness $(p=0.001)$ and openness for experience, the score of nervousness $(\mathrm{p}=0.001)$ is significant as well. It is no doubt that such combination of emotional and behaviour problems and individual person's features significantly disturbs the unity of teenager's socialization and adaptation processes. The results show that context of psychosocial maturity variables is important; and especially in autonomy (individual functioning) and social responsibility as an input that creates societal welfare. Characteristics of psychosocial maturity that were developed are developing now in the interaction with many negative environmental factors. Three psychosocial aspects in teenagers' capability to accept individual decisions and be responsible play role. Firstly, responsibility, including self-confidence, evidence of identity and independence; secondly, perspective, that determines person's ability to assess widely situation in the social context; and finally third - tolerance, that determines suppression of impulsiveness and assessment of situation before acting.

Analyzing person's emotional response to the situation is likely influenced more by individual situation or its interpretation rather than the essence of the situation. It is obvious that such important factors as experience in family, belonging to determined social class and interrelations with environment are closely connected with socially unacceptable behaviour, and such behavioural expression of teenagers who are in the institutional care further gets to be acceptable as a behavioural norm. Analyzing category of teenager's manifestations of emotions and behaviour 9 subcategories were defined (see Table 2) in which some tendencies of "acceptable" norms of behaviour were revealed.

Table 2. Manifestations of striving for negative advantage in societal and institutional environment.

\begin{tabular}{lc}
\hline \multicolumn{1}{c}{ Subcategory } & $\begin{array}{c}\text { Rate of lexical } \\
\text { semantic units }\end{array}$ \\
\hline $\begin{array}{l}\text { Juvenile vagrancy; withdrawal from care institutions and disturbance of institutional rules as } \\
\text { tendency of revolt against rules and universally accepted order. }\end{array}$ & 22 \\
$\begin{array}{l}\text { Manifestation of demonstrative behaviour in society by juvenile delinquents: insolence, } \\
\text { unpredictable and scandalizing behaviour, swear-words. }\end{array}$ & 24 \\
Juvenile aggression: physical and psychical violence against other teenagers and adults, & 22 \\
harming those who are weaker. & 16 \\
Stealing and other undefined offences done by juvenile delinquents.
\end{tabular}




\begin{tabular}{|c|c|}
\hline $\begin{array}{l}\text { Ruffian behaviour of juvenile delinquents destroying property, disturbing public order, by } \\
\text { manifesting demonstrative, provocative actions. }\end{array}$ & 7 \\
\hline $\begin{array}{l}\text { Interpersonal relationships of juvenile delinquents and relationship with other persons that } \\
\text { have harmful influence on the processes of child education: form harmful habits; induce } \\
\text { delinquent behaviour, school nonattendance. }\end{array}$ & 4 \\
\hline Open verbal taunting of adults. & 6 \\
\hline
\end{tabular}

From the dominating and provocative forms of behaviour against definite order that was set up in the research a premise could be made, that teenagers that are placed into institutional care try to fix their position using the type of behaviour that for others (pedagogical staff, peers) it could be decoded as the demonstration of advantage, trying to change or influence institutional pecking order. The main problem is not in the single manifestations of such cases or actions, it is in tendency of that situation to get systemic and it is common for the largest part of teenagers who are in the institutional care. It is obvious that teenagers using insolent, demonstrative and aggressive behaviour try to define themselves, to attract attention of strangers and persons from nearest environment, and at the same time they try to force others to get into the defensive position, to feel weak and diminished. In such situation the demonstration of advantage gets a specific attribution and transforms to the manifestations of concurrent aggression that are evident more and more often. Concurrent aggression determines complicated and difficult relationships between teenagers, institutional staff as well and with environment in general. Category of striving for negative advantage in educational environment was distinguished analysing data of qualitative research (see Table 3).

Table 3. Striving for negative advantage in educational environment.

\begin{tabular}{lc}
\multicolumn{1}{c}{ Category } & $\begin{array}{c}\text { Rate of lexical } \\
\text { semantic units }\end{array}$ \\
\hline $\begin{array}{l}\text { Manifestation of demonstrative behaviour at school: insolent behaviour, disrespect for } \\
\text { pedagogues and disturbance of lessons. }\end{array}$ & 15 \\
$\begin{array}{l}\text { Defiance of student's rules at school and unprepared lesions as juvenile delinquents revolt } \\
\text { against defined rules. }\end{array}$ & 7 \\
Usage of physical and psychical aggression, violence against other students. & 7 \\
$\begin{array}{l}\text { Conflicts with pedagogues and other students that are arranged purposely. } \\
\text { Manifestations of hooliganism and vandal behaviour destroying institutional property, } \\
\text { negligence with fire. }\end{array}$ & 2 \\
\hline
\end{tabular}

Tendencies of aggression in behaviour of teenagers who are placed into institutional care consolidates contraposition with nearest teenager's environment (pedagogues, other staff and classmates), and this is a reason of alienation of teenagers by others; negative attitudes that are especially expressed in the relations with pedagogues, more often than usual given penalties, academic falls and many other situations that act as the factors of de-socialization, provoke demonstration of striving for negative advantage. Manifestations of physical and psychical aggression (7 propositions), conflict situations ( 2 propositions), etc. are direct examples of striving for advantage at the same time trying to humiliate other person pointing out self power. In such situation other persons are turned to feel as resigned "spectators". Striving for advantage is seen in the judgments of teenagers: "threatening with physical power and using violence he tried to get money from classmates". The tension in the relationships with educational environment is evident in nonattendance of the lessons 
or school, failure in academic results, reflects in negative behaviour with pedagogical staff, as well, in general, disturbs teenager's development of adaptation and socialization processes in the institution and supports manifestation of concurrent relationships, trying to reach advantage and domination against others. The results of narrative research proved the premise that teenagers striving for domination (or strengthening status in hierarchical situation) tends to use extremely aggressive forms of behaviour (see Table 4).

Table 4. Reasons of teenager's getting into institutional care: subjective point of view.

\begin{tabular}{llc}
\hline \multicolumn{1}{c}{ Category } & \multicolumn{1}{c}{ Subcategory } & $\begin{array}{c}\text { Rate of lexical semantic } \\
\text { units }\end{array}$ \\
\hline & $\begin{array}{l}\text { Usage of physical power; stealing others' property; asocial } \\
\text { behaviour, (withdrawal from home, contumacy to defined rules). }\end{array}$ & 10 \\
$\begin{array}{l}\text { Value judgment on } \\
\text { reasons getting into } \\
\text { institutional care. }\end{array}$ & School nonattendance, conflicts with the pedagogues & 4 \\
& $\begin{array}{l}\text { Undefined recognition of personal responsibility as a reason } \\
\text { getting into institutional care. }\end{array}$ & 4 \\
& $\begin{array}{l}\text { Shifting responsibility on parents and friends as a reason getting } \\
\text { into institutional care }\end{array}$ & 19 \\
\hline & $\begin{array}{l}\text { Aggressive behaviour of teenager, manifesting ego trip, and } \\
\text { humiliating others, usage of violence for dominating against } \\
\text { others. } \\
\text { Lodgement the institution } \\
\text { using mode of aggressive } \\
\text { behaviour. }\end{array}$ & $\begin{array}{l}\text { Aggressive behaviour of teenager, manifesting usage of power, } \\
\text { verbal aggression, breaking institution rules. }\end{array}$ \\
& $\begin{array}{l}\text { Aggressive behaviour of teenager as the nodus of individual or } \\
\text { group crimes. } \\
\text { Aggressive behaviour of teenager as a measure to escape } \\
\text { violence coming from environment. }\end{array}$ & 3 \\
\hline
\end{tabular}

The analysis of teenagers' essays proved the hypothesis that aggressive behaviour first of all is orientated to the striving for advantage and domination in the group and prevailing motive "they are against everyone and everyone against them". Some arguments of the teenagers could be pointed out: "to force to think that he is stronger than others" (17 year old); "The same with me - I want to show for others that I'm hardened and others are weak" (14 years old); Seeking for advantage goes through different forms: using physical and verbal aggression, indifference to other persons "you can hit him, humiliate" (17 year old); "they try to intimidate friends, strangers" (17 year old); "to manipulate with people" (14 years old); Such preferences justify position of domination and advantage against others and beginning of it is connected with early child's experience in the family where after processes of parents' alienation the need of child's recognition was growing proportionally and at the same time was disturbing psychical development of the child.

Comparing significant of both categories it is obvious that second one (lodgement the institution using mode of aggressive behaviour) is more important in striving for the advantage against others. It happens so, that in undue need of power and precision courage could turn into the insolence, obedience into timidity, tenderness turns into artfulness, when others are forced to give up, surrender, and obey. Fact of teenager's getting into care institution even consolidates tendencies in changes of behaviour because perverted and negative understanding of environment that has formed in early childhood even after determines impassiveness to others problems, decreases believe in support and sensibility, increases hostility that could be defined as evident signs of concurrent aggression.

\section{Discussion}

The research results prove that for the teenagers that are placed into institutional care internal (anxiety), problems, depression and withdrawal are expressed significantly. Development and 
dynamics of manifestation of mentioned problems are firstly connected with early experiences in the family environment (Vorria et al, 1998; Hukkanen et al 1999; Radzevičienè, 2000; Прихожан, Volume 1, 2012 Толстых, 2005).

External signs of behavioural problems (aggressive and rule breaking behaviour) are common for teenagers as well. These findings correspond to the statements of other researchers (Vorria et al, 1998; Hukkanen et al 1999; Samašonok et al, 2010) who point out the same behavioural problems of children who are placed into the institutional care. The authors mention the importance of early experience in the family in which pro-social and non-secure environment that provokes defensive, feuding and aggressive behaviour is obvious (Pileckaitè-Markovienè, Lazdauskas, 2007; Radzevičienė, 2000; Asher, 1990) and the importance of the situation of teenagers getting into institution care.

After the experience of alienation, insecurity, distrust and anxiety in the family, getting into institutional care teenager is forced to feel these states once more, on the other hand, new environment and intermittent situation in the care institution leads teenager to look for new ways for social interaction and often these ways are limited due to the peculiarities of teenager's psychosocial development. Negative experiences often transform into the lack of self-confidence, missing sense of identity and these problems are compensated through negative attitudes and aggressive behaviour against persons and environment (Steinberg et al, 1994, cit. Žukauskienè, Malinauskienè, 2008). It is complicated for youngster to master new and unusual forms of social interactions that are based on common activities and result planning, social activity and responsibility, because stereotypes of teenagers' behaviour and reactions in the different situations cannot change so fast (in this context conformity culture of organization, input of education, person's motivation for socialization are important). The lack of social skills disturbs optimal development of social networks, determines low level of self control, decreases ability to solve conflict situations constructively and usually they are forced to use known behavioural strategies (to behave aggressively and provocative in order to get advantage). Assessing factors that have interfering influence on personality, it could be mentioned that choice of delinquent behaviour is determined by teenagers wish to demonstrate maturity and dependence from others as well (Thorberry, 2004). Teenagers more tend to behave aggressively in the care institution (Felon Inmates), they are disproportionately inimical to authorities, and especially sensitive over disrespect of pedagogical staff (Toch, 1998). The strive for universal advantage that was named by Adler in the behaviour of teenagers who are placed into institutional care obtains destructive features that additionally influence transforming psychosocial activity, and socialization process of young people. Assessment of the determinants of changes in social behaviour and adequate organization of educational processes in care institutions might be a significant component in changes of organization culture that could help in managing manifestations of concurrent aggression and to shift negative need of advantage into other activities (sport, art, prevocational training, etc.).

\section{Conclusions}

Conclusions based on the presented research proves that a significant condition of the development of person's social behaviour that determines the perspective success of socialization is the compatibility of perception of essential social norms, keeping and giving them sense. This compatibility could be contravened by many interrelating factors. Any social environment could provoke presumptions of delinquent behaviour anyway; the significant factor of risk is the person's institutionalization in different stages of his/her psychosocial development. Person's emotional response to the situation is likely influenced more by individual situation or its interpretation rather than the essence of the situation. It is obvious that such important factors as experience in family, belonging to determined social class and interrelations with environment are closely connected with socially unpredictable behaviour, and such behavioural expression of teenagers who are in the institutional care further gets to be acceptable as a behavioural norm.

From the dominating and provocative forms of behaviour against definite order that was set up in the research a premise could be made, that teenagers that are placed into institutional care try to fix their position using the type of behaviour that by others (pedagogical staff, peers) it could be decoded as the demonstration of advantage, trying to change or influence institutional pecking order. The main problem is not in the single manifestations of such cases or actions, it is in tendency 
OF PSYCHOLOGY

IN THE $21^{\text {st }}$ CENTURY Volume 1, 2012

24

of that situation to get systemic and it is common for the largest part of teenagers who are in the institutional care.

It was revealed that social problems (difficulties in setting up and keeping social contacts with teenagers) are common for the institutionalized teenagers who are turned to behave aggressively, to break behavioural rules and have problems in the concentration of attention. These characteristics are going to transform into complicated interrelations and determine constant competition in the fictitious hierarchy among teenagers.

Concurrent aggression determines complicated and difficult relationships between teenagers, institutional staff as well and with environment in general. Different forms of behaviour (physical and verbal aggression, indifference to other persons) are used by teenagers in seeking for the advantage. Such preferences justify position of domination and advantage against others and beginning of it is connected with early child's experience in the family where after processes of parents' alienation the need of child's recognition was growing proportionally and at the same time was disturbing psychical development of the child.

Fact of teenager's getting into care institution even consolidates tendencies in changes of behaviour because perverted and negative understanding of environment that has formed in early childhood even after determines impassiveness to others problems, decreases believe in support and sensibility, increases hostility that could be defined as evident signs of concurrent aggression.

\section{References}

Adler, A. (2008). Žmogaus pažinimas. Vilnius, Vaga.

Achenbach, T. M., \& Rescoria, L. A. (2001). Manual for the aseba school- age forms and profiles. Burlington, V T: University of Vermont Research Center for Children, Youth, and Families.

Asher, S. R. (1990). Recent advances in the study of peer rejection. Peer Rejection in Childhood. Ed. by Asher, S. R, \& Coie, J. D. Cambridge: Cambridge University Press, 3-14.

Caufman, E., \& Steiberg, L. (2000). Maturity of judgement in adolescents may be less culpable than adults. Behavioural Sciences and the Law, 18, 741-760.

Galambos, N. L., \& Tilton-Weaver, L. C. (2000). Adolescents' psychosocial maturity, subjective age, and problem behavior: In search of the adultoid. Applied Developmental Science, 4, 178-192.

Greenberg, E., \& Sorensen, A. (1974). Toward a concept of psychological maturity. Journal of Youth and Adolescents, 4, 329-357.

Horney, K. (2008). Neurotiška mūsu laiku asmenybė. Vilnius, Apostrofa.

Hukkanen, R., Sourander, A., Bergroth, L., \& Piha, J. (1999). Psychological factors and adequacy of services for children in children's homes. European Child and Adolescent Psychiatry, 4 (81), 251-258.

Kovalenkovienè, J., \& Leliūgienè, I. (2005). Buvusių vaikų globos istaigų auklètiniu socialinė adaptacija profesinèje mokykloje. Ugdymas. Kūno kultūra. Sportas, 5 (59), 41-53.

Pileckaitė - Markovienè, M., \& Lazdauskas, T. (2007). Šeima ir tèvu globos netekusio vaiko raida. Vilnius: Vaga.

Radzevičienė, L. (2000). Ankstyvojo amžiaus deprivuotų vaikų psichosocialinės raidos bruožai, Pedagogika: Mokslo darbai, 45, 92-100.

Rosenberg, F. R., \& Rosenberg, M. (1978). Self-esteem and deliquency. Journal of Youth and Adolescence, 3, 279-294.

Samašonok, K., \& Žukauskienė, R. (2004). Globos namų auklètinių ir vaikų, gyvenančių su abiem tėvais, mokyklinès adaptacijos ir kompetencijos ypatumai. Socialinis darbas, 3 (2), 119-129.

Samašonok, K., Juodraitis, A., \& Gudonis, V. (2010). Globos namuose ir pilnose šeimose gyvenančių paaugliu asmenybès bruožų ir elgesio bei emocinių sunkumu ypatumai. Ugdymo psichologija, 21, 23-34.

Stoff, D. M., Breiling, J., \& Maser, J. D. (1997). Handbook of antisocial behaviour. New York: John Willey.

Thornberry, T. P. (2004). Development theories of crime and delinquency. Transaction Publisher, New Brunswick, New Jersey. 
Toch, H. (1998). Hypermaculinity and prison violence in USA. Bonker, Lee H. (Ed), Masculinities and violence. London, New Delhi: Sage Publications, 168-179.

Turner, R. H., \& Kiluan, L. M. (1972), (Ed). Collective behaviour 2 ${ }^{\text {nd, }}$ Englewood Clifs; NJ: Prentice-Hall.

Vorria, P., Wolkind, S., Rutter, M., Pickles, A., \& Hobsbaum, A. (1998). A comparative study of Greek children in long-term residential group care and in two-parent families: Social emotional and behavioural differences. Journal of Child Psychology and Psychiatry and Allied Disciplines, 39 (2), 225-236.

Walters, G. D., \& White, T. W. (1990). The thinking criminal: A cognitive model of lifestyle criminality. Journal of Offender Rehabilitation, 16, 1-26.

Žukauskienè, R., \& Malinauskienè, O. (2008). Skirtumai tarp lyčiu, prognuozuojant elgesio ir emocinius sunkumus paauglystėje pagal asmenybès bruožus ir tėvų auklëjimo stilių. Psichologija: Mokslo darbai, $38,63-83$.

Ослон, В. Н. (2001). Замещающая профессиональная семья как одна из моделей решения проблемы сиротсва. Вопросы психологии, 3, 79-90.

Ярославцева, И. В. (2002). Депривированный подросток личностный и психофизиологифеский потенциял адаптации. Дефектология, 5, 28-32.

Advised by Jan Lašek, University of Hradec Kralove, Czech Republic

Received: February 10, 2012

Accepted: March 12, 2012

Adolfas Juodraitis Associate Professor, Department of Social Education and Psychology, Faculty of Social

Welfare and Disability Studies, Šiauliai University

P.Visinskio Street 25, LT-76351, Siauliai, Lithuania.

Phone: +370 41595732 .

E-mail: sppkatedra@cr.su.tt

Website: http://www.su.ti 